\title{
Biochemical effects of piceatannol in human HL-60 promyelocytic leukemia cells - Synergism with Ara-C
}

\author{
MONIKA FRITZER-SZEKERES ${ }^{1}$, IVO SAVINC ${ }^{1}$, ZSUZSANNA HORVATH ${ }^{1}$, PHILIPP SAIKO ${ }^{1}$, \\ MICHAEL PEMBERGER $^{1}$, GERALDINE GRASER ${ }^{1}$, ASTRID BERNHAUS ${ }^{1}$, MARIA OZSVAR-KOZMA ${ }^{1}$, \\ MICHAEL GRUSCH ${ }^{2}$, WALTER JAEGER ${ }^{3}$ and THOMAS SZEKERES ${ }^{1}$
}

\begin{abstract}
${ }^{1}$ Clinical Institute of Medical and Chemical Laboratory Diagnostics, Medical University of Vienna, General Hospital of Vienna, Waehringer Guertel 18-20, A-1090 Vienna; ${ }^{2}$ Department of Medicine I, Division of Cancer Research, Medical

University of Vienna, Borschkegasse 8a, A-1090 Vienna; ${ }^{3}$ Department for Clinical Pharmaceutics and Diagnostics, Faculty of Health Sciences, University of Vienna, Althanstrasse 14, A-1090 Vienna, Austria
\end{abstract}

Received April 7, 2008; Accepted June 2, 2008

DOI: 10.3892/ijo_00000077

\begin{abstract}
Piceatannol (3,3',4,5'-tetrahydroxy-trans-stilbene; PCA) is a naturally occurring metabolite of resveratrol (3,4',5-trihydroxy-trans-stilbene; RV). In this study, we identified additional biochemical targets of PCA in human HL-60 promyelocytic leukemia cells. Incubation with PCA led to a significant proportion of apoptotic cells and caused an arrest in the G2-M phase of the cell cycle. PCA depleted intracellular dCTP and dGTP pools, and inhibited the incorporation of ${ }^{14} \mathrm{C}$-labeled cytidine into DNA. PCA significantly abolished all NTP pools, and sequential treatment with PCA and Ara-C yielded synergistic growth inhibitory effects because of remarkably increased Ara-CTP formation after PCA preincubation. Due to these promising results, PCA may support conventional chemotherapy of human malignancies and therefore, deserves further preclinical and in vivo testing.
\end{abstract}

\section{Introduction}

Piceatannol (3,3',4,5'-tetrahydroxy-trans-stilbene; PCA), is a natural product present in various berries, plants and grapes as well as in wine. It can be metabolized by cytochrome P450 isoenzymes from resveratrol (3,4',5-trihydroxy-transstilbene, RV; chemical structures of RV and PCA are depicted in Fig. 1), one of the compounds in red wine, which might cause the 'French paradox' $(1,2)$. This is the fact, that the incidence of coronary heart disease in France is significantly (40\%) lower than in the rest of Europe. As the diet in France cannot be made responsible for this difference, it was assumed

Correspondence to: Dr Thomas Szekeres, Clinical Institute of Medical and Chemical Laboratory Diagnostics, Medical University of Vienna, General Hospital of Vienna, Waehringer Guertel 18-20, A-1090 Vienna, Austria

E-mail: thomas.szekeres@meduniwien.ac.at

Key words: resveratrol, piceatannol, Ara-C, leukemia, ribonucleotide reductase, apoptosis that the relatively high wine consumption could play a role. Among various beneficial ingredients of wine, in particular red wine, RV was identified as one compound with biochemical effects, such as excellent free radical scavenging capacities, which might be beneficial for the prevention of heart disease. In addition, RV was shown to be able to stabilize DNA by activating sirtuins and to cause apoptosis in tumor cells (3). However, it is known, that under physiological conditions only relatively small amounts of free RV are being absorbed (4). Nevertheless, metabolites, such as glucuronides, sulfate conjugates or hydroxylated RV molecules are present in the serum and might also exert beneficial effects after wine consumption. One of these metabolites is PCA, a monohydroxylated RV derivative.

PCA was shown to be an effective free radical scavenger and to inhibit inflammation, carcinogenesis and cancer cell growth (5-9). It was demonstrated to be a potent inducer of apoptosis in various tumor cells, such as melanoma, lymphoma or leukemia cell lines (10-12) and to inhibit tyrosine kinase activity in malignant cells (13-15). In particular, it was previously reported to be a Syk/ZAP70-specific kinase inhibitor, which selectively inhibits the tyrosine phosphorylation of STAT3 and STAT5 (16). As upregulation of these signal transduction pathways plays a crucial role in leukemia and inhibition of tyrosine kinases is one of the most promising approaches to treat various forms of leukemia, we investigated the biochemical effects of PCA in the human HL-60 promyelocytic leukemia cell line $(17,18)$.

In particular the possible target enzyme of PCA, ribonucleotide reductase (RR) was studied. Resveratrol was already shown to be an effective inhibitor of RR, an enzyme that proved to be an excellent target for antitumor and antileukemic therapy $(19,20)$. The enzyme is upregulated in rapidly proliferating malignant cells, and has low activity in normal cell populations, thus enzyme inhibition selectively targets malignant cells. Potent antitumor and antileukemic compounds such as hydroxyurea, gemcitabine or fludarabine are inhibitors of this enzyme $(21,22)$. The effect of PCA on ribonucleotide concentrations was therefore investigated. In this study we show for the first time that PCA inhibits RR 

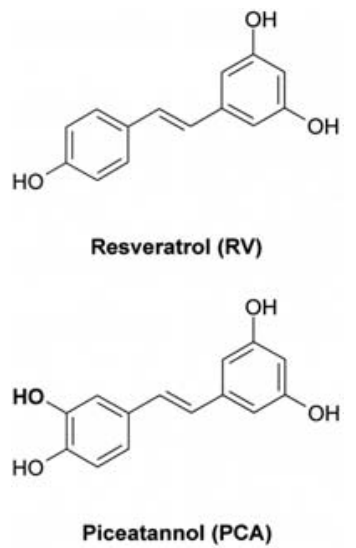

Figure 1. Chemical structures of resveratrol and piceatannol.

in situ activity and depletes intracellular dNTP (deoxynucleoside triphosphate) pools. Cell cycle phase distribution was studied after PCA treatment of HL-60 cells and induction of apoptosis was investigated using a Hoechst/propidium iodide double staining method.

Concerning leukemia therapy, Ara-C is one of the most effective drugs used. It is administered in combination with other drugs and due to the emergence of resistant cell clones, new drug combinations are needed for improved outcome. As depletion of dCTP might, as a consequence of deoxycytidine-kinase activation, increase the formation of Ara-CTP, the active metabolite of cytarabine (Ara-C), we investigated the combination effects of PCA and Ara-C. Such drug combinations could offer additional options for chemotherapeutic treatment by limiting side effects and postponing the development of resistance; in addition, it is known that various inhibitors of RR can synergistically enhance the effects of Ara-C (23).

\section{Materials and methods}

Chemicals. Piceatannol (PCA) and Ara-C were purchased from Sigma, St. Louis, MO, USA. All other reagents used were of highest purity available.

Cell culture. HL-60 human promyelocytic cells were purchased from ATCC (American Type Culture Collection, Manassas, VA, USA). The cells were maintained in logarithmical growth in RPMI-1640 medium supplemented with $10 \%$ heat inactivated fetal calf serum, $1 \%$ L-glutamine and $1 \%$ penicillin/streptomycin at $37^{\circ} \mathrm{C}$ in a humidified atmosphere containing $5 \% \mathrm{CO}_{2}$. All media and supplements were obtained from Life Technologies, Paisley, Scotland, UK.

Growth inhibition assay. HL-60 cells were seeded in $25-\mathrm{cm}^{2}$ tissue culture flasks at a concentration of $0.1 \times 10^{6}$ per $\mathrm{ml}$ and incubated with various concentrations of PCA (3.125, 6.25, 12.5 and $25 \mu \mathrm{M})$. Cell counts and $\mathrm{IC}_{50}$ values for PCA were determined after 3 days using a CC-108 microcellcounter (SYSMEX, Kobe, Japan).

Determination of deoxyribonucleoside triphosphates. A slightly modified method, originally described by Garrett and Santi was used (24). HL-60 cells $\left(7 \times 10^{7}\right)$ were incubated with 10,20 and $40 \mu \mathrm{M}$ PCA for $24 \mathrm{~h}$. Then $1 \times 10^{8}$ were centrifuged at $1800 \mathrm{rpm}$ and resuspended in $100 \mu 1$ phosphatebuffered saline and extracted with $10 \mu 1$ trichloracetic acid. The lysate was rested on ice and neutralized by adding $1.5 \mathrm{Vol}$ of freon containing $0.5 \mathrm{~mol} / \mathrm{l}$ tri-n-octylamin. Afterwards the lysate was centrifuged (15000 rpm for $4 \mathrm{~min}$ ) and the superior part was taken for the periodation: $100 \mu \mathrm{l}$ extract + $30 \mu 1$ methylamin $(\mathrm{pH} 7.5 ; 4 \mathrm{M})+10 \mu 1$ periodate. Aliquots $(120 \mu 1)$ of the sample were analyzed using a Merck 'La Chrom' HPLC-system (Merck, Germany) equipped with D-7000 interface, L-7100 pump, L-7200 autosampler, and L-7400 UV-detector. Detection time was set at $80 \mathrm{~min}$, the detector operated on $280 \mathrm{~nm}$ for $40 \mathrm{~min}$ and then switched to $260 \mathrm{~nm}$ for another $40 \mathrm{~min}$. Samples were eluted with a $3.2 \mathrm{M}$ ammonium phosphate buffer, $\mathrm{pH} 3.6$ ( $\mathrm{pH}$ adjusted by addition of $3.2 \mathrm{mM} \mathrm{H}_{3} \mathrm{PO}_{4}$ ), containing $20 \mathrm{M}$ acetonitrile using a 4.6x250 mm PARTISIL 10 SAX column (Whatman Ltd., Kent, UK). Separation was performed at constant ambient temperature and a flow rate of $2 \mathrm{ml}$ per minute. The concentration of each dNTP was then calculated as percent of total area under the curve for each sample. NTP and AraCTP determinations were performed according to the same method without the periodation step.

Determination of ribonucleotide reductase in situ activity. For elucidating the changes of ribonucleotide reductase in situ activity, exponentially growing HL-60 cells $\left(5 \times 10^{6}\right)$ were incubated with 20 and $40 \mu \mathrm{M}$ PCA for $24 \mathrm{~h}$ at $37^{\circ} \mathrm{C}$ in a humidified atmosphere containing $5 \% \mathrm{CO}_{2}$. The cells were then pulsed with ${ }^{14} \mathrm{C}$-cytidine $(3.125 \mu \mathrm{l}$ in $5 \mathrm{ml}$ cellsuspension) for $30 \mathrm{~min}$ at $37^{\circ} \mathrm{C}$. Cells were collected by centrifugation (1200 rpm, $5 \mathrm{~min}$ ), washed twice with PBS and processed to extract total genomic DNA. We then measured the radioactivity in the DNA samples, which corresponds to the converted cytidine.

Hoechst dye 33258 and propidium iodide double staining. HL-60 cells $\left(0.4 \times 10^{6}\right.$ per $\left.\mathrm{ml}\right)$ were seeded in $25-\mathrm{cm}^{2}$ Nunc tissue culture flasks and exposed to increasing concentrations of PCA for 24 h. Hoechst 33258 (HO, Sigma) and propidium iodide (PI, Sigma) were added directly to the cells to final concentrations of $5 \mu \mathrm{g} / \mathrm{ml}$ and $2 \mu \mathrm{g} / \mathrm{ml}$, respectively. After 60 min of incubation at $37^{\circ} \mathrm{C}$, cells were examined on a Leica DMR XA fluorescence microscope (Leica, Wetzlar, Germany) equipped with appropriate filters for Hoechst 33258 and PI. Cells were photographed with a COHU high performance CCD camera (COHU Inc., San Diego, CA, USA) using Leica Q-fish software. This method allows distinguishing between apoptosis and necrosis. Cells were judged according to their morphology and the integrity of their cell membranes, which can easily be seen after propidium iodide staining.

Cell cycle distribution analysis. HL-60 cells $\left(0.4 \times 10^{6}\right.$ per ml) were seeded in $25-\mathrm{cm}^{2}$ Nunc tissue culture flasks and incubated with 5,10 and $20 \mu \mathrm{M}$ of PCA at $37^{\circ} \mathrm{C}$ under cell culture conditions. After $24 \mathrm{~h}$, cells were harvested and suspended in $5 \mathrm{ml}$ cold PBS, centrifuged (600 rpm for $5 \mathrm{~min}$ ), resuspended and fixed in $3 \mathrm{ml}$ cold ethanol $(70 \%)$ for $30 \mathrm{~min}$ at $4^{\circ} \mathrm{C}$. After two washing steps in cold PBS RNAse A 
Table I. Growth inhibition assay, sequential incubation of HL-60 cells with piceatannol for $24 \mathrm{~h}$ and Ara-C for $48 \mathrm{~h}$.

\begin{tabular}{|c|c|c|c|c|}
\hline Compound & Concentration & Cell number ( $\%$ of control) & Predicted value ${ }^{a}$ & Combination index \\
\hline Piceatannol (A) & 5 & 90.9 & & \\
\hline \multirow[t]{2}{*}{$(\mu \mathrm{M})$} & 10 & 69.5 & & \\
\hline & 20 & 20.4 & & \\
\hline Ara-C (B) & 2.5 & 90.8 & & \\
\hline \multirow[t]{3}{*}{$(\mathrm{nM})$} & 5 & 84.4 & & \\
\hline & 10 & 76.3 & & \\
\hline & 15 & 68.3 & & \\
\hline Piceatannol & 5 & & & \\
\hline+ Ara-C & 2.5 & 85.4 & 82.5 & 1.412 \\
\hline Piceatannol & 5 & & & \\
\hline+ Ara-C & 5 & 83.5 & 76.7 & 1.683 \\
\hline Piceatannol & 5 & & & \\
\hline+ Ara-C & 10 & 77.2 & 69.4 & 1.670 \\
\hline Piceatannol & 5 & & & \\
\hline+ Ara-C & 20 & 60.3 & 62.0 & 1.112 \\
\hline Piceatannol & 10 & & & \\
\hline+ Ara-C & 2.5 & 55.7 & 63.1 & $0.881^{\mathrm{b}}$ \\
\hline Piceatannol & 10 & & & \\
\hline+ Ara-C & 5 & 45.3 & 58.7 & $0.743^{\mathrm{b}}$ \\
\hline Piceatannol & 10 & & & \\
\hline+ Ara-C & 10 & 40.6 & 53.0 & $0.711^{\mathrm{b}}$ \\
\hline Piceatannol & 10 & & & \\
\hline+ Ara-C & 20 & 31.8 & 47.5 & $0.628^{b}$ \\
\hline Piceatannol & 20 & & & \\
\hline+ Ara-C & 2.5 & 16.5 & 18.5 & $0.645^{\mathrm{b}}$ \\
\hline Piceatannol & 20 & & & \\
\hline+ Ara-C & 5 & 14.7 & 17.2 & $0.607^{\mathrm{b}}$ \\
\hline Piceatannol & 20 & & & \\
\hline+ Ara-C & 10 & 12.5 & 15.6 & $0.556^{\mathrm{b}}$ \\
\hline Piceatannol & 20 & & & \\
\hline+ Ara-C & 20 & 10.6 & 13.9 & $0.517^{b}$ \\
\hline
\end{tabular}

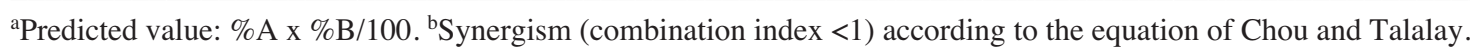

and propidium iodide were added to a final concentration of $50 \mu \mathrm{g} / \mathrm{ml}$ each and incubated at $4^{\circ} \mathrm{C}$ for 60 min before measurement. Cells were analysed on a FACSCalibur flow cytometer (BD Biosciences, San Jose, CA, USA) and cell cycle distribution was calculated with ModFit LT software (Verity Software House, Topsham, ME, USA).

Statistical calculations. Dose-response curves were calculated using the Prism 4.03 software package (GraphPad, San Diego, CA, USA) and statistical significance was determined by unpaired $t$-test. The calculations of combination effects were performed using the 'Calcusyn' software designed by Chou and Talalay (Biosoft, Ferguson, MO, USA) (25).

\section{Results}

Growth inhibition of human HL-60 cells by piceatannol. After incubation of human promyelocytic HL-60 cells with 5, 10 , and $20 \mu \mathrm{M}$ of PCA, an $\mathrm{IC}_{50}$ value (50\% growth inhibition in comparison with untreated control cells) of $14 \mu \mathrm{M}$ was observed after 3 days of drug incubation.

Combination effects of piceatannol and Ara-C on the growth on HL-60 cells. HL-60 cells were first incubated with different concentrations of PCA $(5,10$ and $20 \mu \mathrm{M})$ for $24 \mathrm{~h}$. Then PCA was washed out and cells were incubated in drug free medium (control) or were exposed to various concentrations 

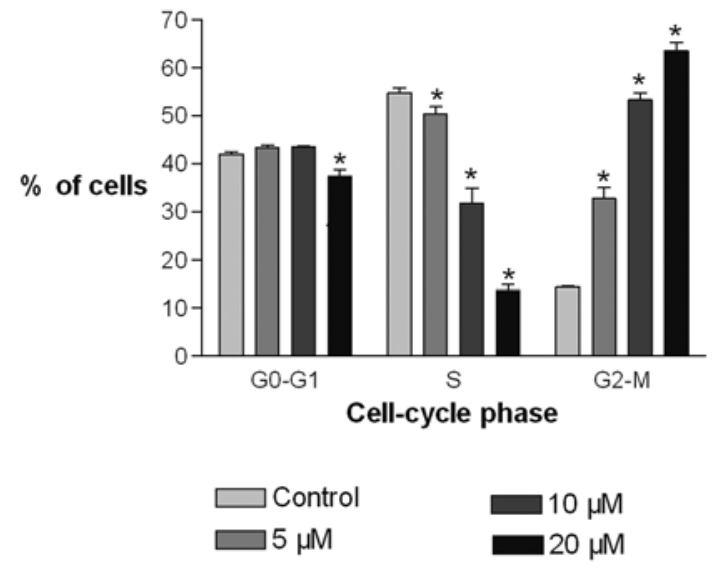

Figure 2. Effect of piceatannol on the cell cycle phase distribution of HL-60 cells. Values are means $\pm \mathrm{SE}$ of three determinations out of one representative experiment. Significant differences $(\mathrm{p}<0.05)$ are marked with an asterisk.

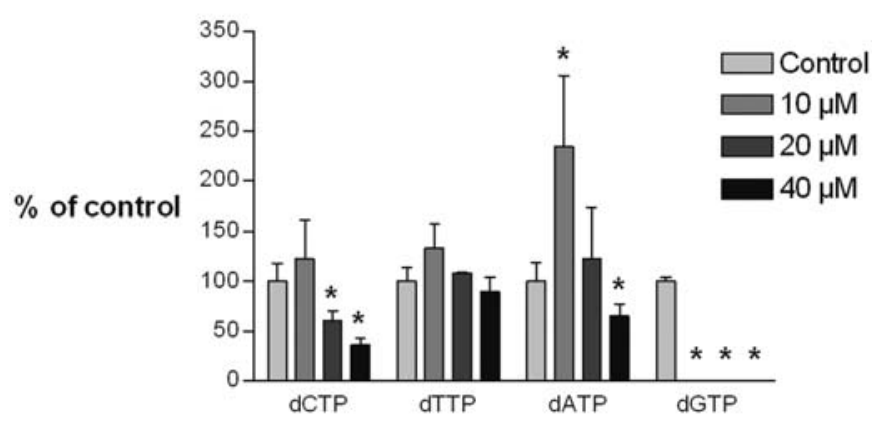

Figure 3. Effect of piceatannol incubation (24 h) on dNTP pool size in HL-60 cells. Data are means \pm SE of three determinations out of one representative experiment. Significant differences $(\mathrm{p}<0.05)$ are marked with an asterisk.

of Ara-C (2.5-15 nM) for another $48 \mathrm{~h}$. After that period cells were counted using a microcellcounter. Most combinations yielded highly synergistic results according to the equation of Chou and Talalay, which is shown in Table I. Eight out of twelve combination indices were $<1$, which indicate more than additive or synergistic growth inhibitory effects of the combination treatment.

Effect of piceatannol on the cell cycle phase distribution of HL-60 cells. Cells were incubated with 5, 10 and $20 \mu \mathrm{M}$ PCA for $24 \mathrm{~h}$, and cell cycle phase distribution was determined by FACS analysis. A concentration-dependent significant decrease of cells in the $\mathrm{S}$ phase was observed and accompanied by a significant increase of cell fractions in the G2/M phase of the cell cycle. These results indicate the inhibition of cell cycle progression in the $\mathrm{G} 2 / \mathrm{M}$ phase of the cell cycle after incubation with PCA. Results are shown in Fig. 2.

Effect of piceatannol on the dNTP pool sizes in HL-60 cells. Cells were treated with 10,20 and $40 \mu \mathrm{M}$ PCA for $24 \mathrm{~h}$. Then dNTP concentrations were determined by HPLC analysis.

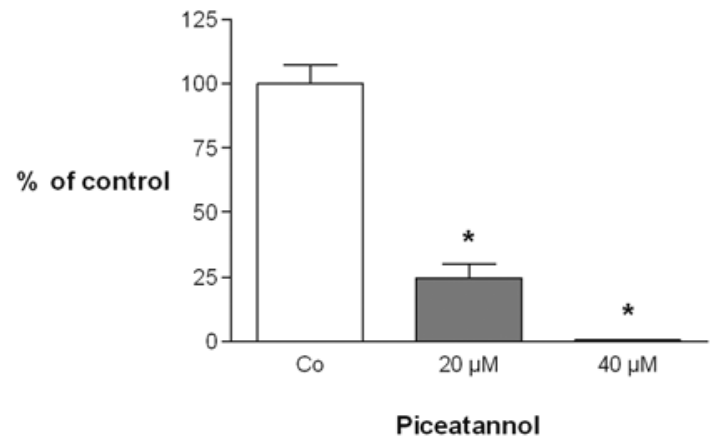

Figure 4. Effect of piceatannol on ribonucleotide reductase in situ activity (incorporation of ${ }^{14} \mathrm{C}$-cytidine into DNA of HL-60 cells). Data are means \pm $\mathrm{SE}$ of three determinations out of one representative experiment. Significant differences $(\mathrm{p}<0.05)$ are marked with an asterisk.

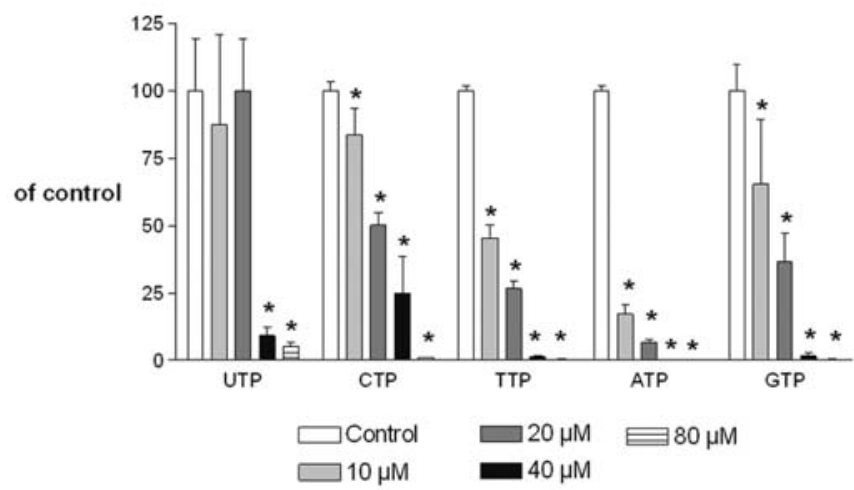

Figure 5. Effect of piceatannol incubation on NTP pool sizes in HL-60 cells. Data are means \pm SE of three determinations out of one representative experiment. Significant differences $(\mathrm{p}<0.05)$ are marked with an asterisk.

Significant changes were observed for dCTP and dATP concentrations which decreased after incubation with PCA. DGTP pools decreased to levels under the detection limit after incubation with $10 \mu \mathrm{M}$ PCA. Results are shown in Fig. 3.

Effect of piceatannol incubation on ribonucleotide reductase in situ activity. To determine ribonucleotide reductase in situ activity, cells were first preincubated with 20 and $40 \mu \mathrm{M}$ PCA and then pulse-labeled with ${ }^{14} \mathrm{C}$-cytidine. The inhibition of radiolabeled cytidine incorporation into the tumor cell DNA correlates with the in situ inhibition of ribonucleotide reductase activity. As shown in Fig. 4, preincubation with $20 \mu \mathrm{M}$ PCA decreased ${ }^{14} \mathrm{C}$-cytidine incorporation to $24 \%$ of control values and preincubation with $40 \mu \mathrm{M}$ PCA completely blocked ${ }^{14} \mathrm{C}$-cytidine incorporation.

Effect of piceatannol on the NTP (nucleoside triphosphate) pool sizes in HL-60 cells. HL-60 cells were incubated with $10,20,40$ and $80 \mu \mathrm{M}$ PCA for $24 \mathrm{~h}$ and then analyzed by HPLC for changes in NTP pools. After incubation with $10 \mu \mathrm{M}$ PCA all NTP pools with the exception of UTP dropped significantly. UTP pools decreased to significantly lower concentrations than the control values after incubation with 


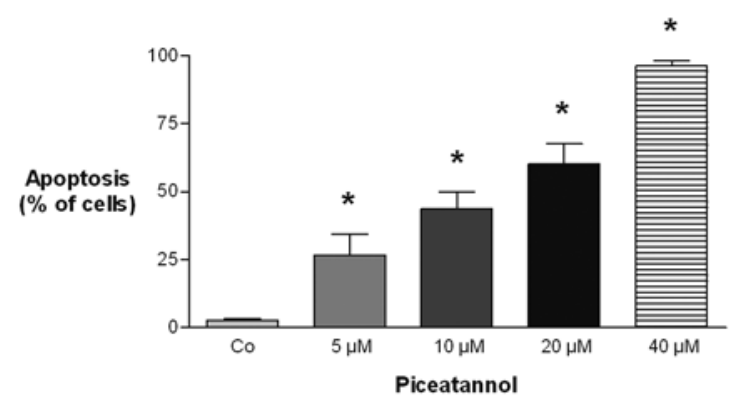

Figure 6. Induction of apoptosis after piceatannol treatment. Cells were incubated with various concentrations of piceatannol for $24 \mathrm{~h}$, and then cells displaying signs of apoptosis were determined morphologically after Hoechst/propidium iodide double staining. Data are means \pm SE of three determinations out of one representative experiment. Significant differences $(\mathrm{p}<0.05)$ are marked with an asterisk

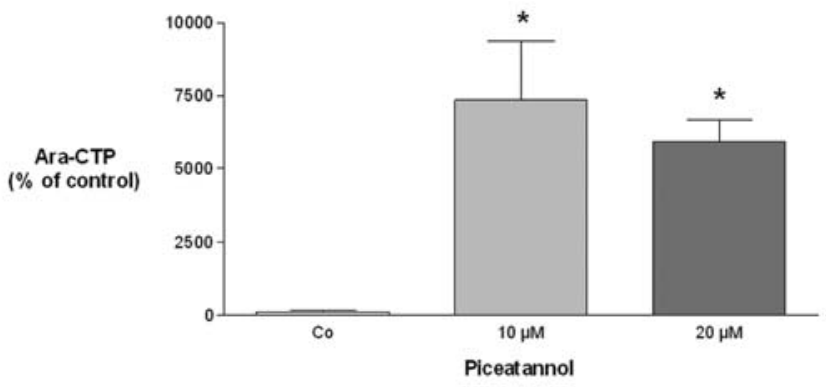

Figure 7. Effect of piceatannol pretreatment on the formation of Ara-CTP. Data are means \pm SE of three determinations. Significant differences $(\mathrm{p}<0.05)$ are marked with an asterisk.

$40 \mu \mathrm{M}$ PCA. The most pronounced effects were seen for ATP concentrations which decreased to $17 \%$ of control values after incubation with $10 \mu \mathrm{M}$ PCA. ATP pools dropped to values under the detection limit when cells were incubated with 40 or $80 \mu \mathrm{M}$ PCA. Results are shown in Fig. 5.

Induction of apoptosis after incubation with piceatannol. The induction of apoptosis was examined using the Hoechst/ propidium iodide double staining method. This method allows distinguishing between apoptosis and necrosis and can determine early morphological signs of apoptosis. Incubation of HL-60 cells with increasing concentrations of PCA $(5,10$, 20 , and $40 \mu \mathrm{M}$ ) showed a dose-dependent increase of the number of apoptotic cells. After incubation with $40 \mu \mathrm{M}$ PCA, $96 \%$ of cells showed early signs of apoptosis. Results are shown in Fig. 6.

Effect of piceatannol preincubation on Ara-CTP pool sizes in $H L-60$ cells. Cells were preincubated with 10 or $20 \mu \mathrm{M}$ PCA for $24 \mathrm{~h}$. After incubating the cells with $10 \mu \mathrm{M}$ Ara-C for $4 \mathrm{~h}$, the Ara-CTP formation was determined by HPLC. AraCTP is the active metabolite of Ara-C and is responsible for the antileukemic effects of the compound. Results are shown in Fig. 7. A significant increase (7300- and 5900-fold after preincubation with 10 or $20 \mu \mathrm{M}$ PCA, respectively) of Ara-CTP concentrations was observed.

\section{Discussion}

Piceatannol (PCA) is a monohydroxylated resveratrol analogue and was described to have various effects, which differ from the biochemical effects of resveratrol (RV) itself. Selective inhibition of cyclooxygenase 2 was only observed for PCA; similarly, upregulation of endothelial heme oxygenase 1 was seen after PCA incubation and not after RV treatment $(26,27)$. Other effects, like the free radical scavenging effects can be caused by both compounds; however, additional hydroxyl groups, such as present in the PCA molecule could enhance the effects seen with RV (7). These data indicate that although both structures are very closely related, the introduction of only one additional hydroxyl moiety can significantly alter the biochemical effects of RV.

In the present study, we focused our interest on the enzyme ribonucleotide reductase, which is an important target for antitumor therapy (20). The enzyme is significantly upregulated in malignant cells and rate limiting for de novo DNA synthesis. It has been shown that PCA inhibits the in situ activity of RR and depletes dCTP and dGTP pools, which are products of the enzyme. NTP pools, in particular intracellular ATP could also significantly be depleted by PCA. As dNTP and NTP imbalance can play a role for the induction of apoptosis, we examined the induction of programmed cell death after PCA incubation. It was known that PCA induces apoptosis by inhibiting IкB kinase or STAT3, however ATP depletion also plays a role, and thus various mechanisms might be jointly responsible for the observed induction of apoptosis (28-30).

It was first shown by Ferrigni and coworkers (31) that PCA is active against leukemia cells. Recently PCA was demonstrated to induce apoptosis in MDR and BCR-ABLexpressing leukemia cells (12). The Syk inhibitor PCA blocks the Syk homologue ZAP-70 (zeta-associated protein of $70 \mathrm{kDa}$ ), a protein tyrosine kinase, which is essential for $\mathrm{T}$ cell receptor signal transduction. ZAP-70 positivity is closely related to the prognosis of both early and advanced CLL, thereby indicating more rapid disease progression and shorter survival (32). However, inhibition of ZAP-70 might also be important for the treatment of myeloid leukemia, as shown by Balaian and coworkers (17). The high specificity of PCA might therefore be important for treatment of leukemia patients $(17,33)$.

In clinical practice various drug combinations are being used for the treatment of leukemia. The most effective single compound is Ara-C. It has to be phosphorylated by the enzyme deoxycytidine kinase to its triphosphate Ara-CTP to be active. This phosphorylation step is feed back inhibited by dCTP; therefore, depletion of dCTP prior to Ara-C treatment can increase Ara-CTP pools and synergistically enhance the cytotoxic effects of Ara-C. We showed that PCA indeed significantly increases Ara-CTP pools and synergistically inhibits leukemia cell growth when HL-60 cells were sequentially incubated first with PCA and then with Ara-C.

Due to manifold beneficial biochemical effects, such as inhibition of ZAP-70, cyclooxygenase 2, ribonucleotide reductase, inhibition of cell cycle progression, induction of 
apoptosis, and the synergism with Ara-C, we believe that PCA could be a promising compound for the treatment of various types of leukemia. Therefore, further in vitro and animal studies are warranted.

\section{Acknowledgements}

This work was supported by a grant of the 'Medizinisch Wissenschaftlicher Fonds des Bürgermeisters der Bundeshauptstadt Wien' grant no. 2296 to T.S.

\section{References}

1. Potter GA, Patterson LH, Wanogho E, Perry PJ, Butler PC, Ijaz T, Ruparelia KC, Lamb JH, Farmer PB, Stanley LA and Burke MD: The cancer preventative agent resveratrol is converted to the anticancer agent piceatannol by the cytochrome P450 enzyme CYP1B1. Br J Cancer 86: 774-778, 2002.

2. Renaud S and de Lorgeril M: Wine, alcohol, platelets, and the French paradox for coronary heart disease. Lancet 339: 1523-1526, 1992.

3. Howitz KT, Bitterman KJ, Cohen HY, Lamming DW, Lavu S, Wood JG, Zipkin RE, Chung P, Kisielewski A, Zhang LL, Scherer B and Sinclair DA: Small molecule activators of sirtuins extend Saccharomyces cerevisiae lifespan. Nature 425: 191-196, 2003.

4. Goldberg DM, Yan J and Soleas GJ: Absorption of three winerelated polyphenols in three different matrices by healthy subjects. Clin Biochem 36: 79-87, 2003.

5. Wolter F, Clausnitzer A, Akoglu B and Stein J: Piceatannol, a natural analog of resveratrol, inhibits progression through the $\mathrm{S}$ phase of the cell cycle in colorectal cancer cell lines. J Nutr 132: 298-302, 2002.

6. Hung LM, Chen JK, Lee RS, Liang HC and Su MJ: Beneficial effects of astringinin, a resveratrol analogue, on the ischemia and reperfusion damage in rat heart. Free Radic Biol Med 30: 877-883, 2001.

7. Murias M, Jager W, Handler N, Erker T, Horvath Z, Szekeres T, Nohl H and Gille L: Antioxidant, prooxidant and cytotoxic activity of hydroxylated resveratrol analogues: structure-activity relationship. Biochem Pharmacol 69: 903-912, 2005.

8. Estrov Z, Shishodia S, Faderl S, Harris D, Van Q, Kantarjian HM, Talpaz M and Aggarwal BB: Resveratrol blocks interleukin1beta-induced activation of the nuclear transcription factor NFkappaB, inhibits proliferation, causes S-phase arrest, and induces apoptosis of acute myeloid leukemia cells. Blood 102: 987-995, 2003.

9. Richard N, Porath D, Radspieler A and Schwager J: Effects of resveratrol, piceatannol, tri-acetoxystilbene, and genistein on the inflammatory response of human peripheral blood leukocytes. Mol Nutr Food Res 49: 431-442, 2005.

10. Larrosa M, Tomas-Barberan FA and Espin JC: The grape and wine polyphenol piceatannol is a potent inducer of apoptosis in human SK-Mel-28 melanoma cells. Eur J Nutr 43: 275-284, 2004.

11. Wieder T, Prokop A, Bagci B, Essmann F, Bernicke D, Schulze-Osthoff K, Dorken B, Schmalz HG, Daniel PT and Henze G: Piceatannol, a hydroxylated analog of the chemopreventive agent resveratrol, is a potent inducer of apoptosis in the lymphoma cell line $\mathrm{BJAB}$ and in primary, leukemic lymphoblasts. Leukemia 15: 1735-1742, 2001.

12. Tolomeo M, Grimaudo S, Di Cristina A, Roberti M, Pizzirani D, Meli M, Dusonchet L, Gebbia N, Abbadessa V, Crosta L, Barucchello R, Grisolia G, Invidiata F and Simoni D: Pterostilbene and 3'-hydroxypterostilbene are effective apoptosisinducing agents in MDR and BCR-ABL-expressing leukemia cells. Int J Biochem Cell Biol 37: 1709-1726, 2005.

13. Geahlen RL and McLaughlin JL: Piceatannol (3,4,3',5'-tetrahydroxy-trans-stilbene) is a naturally occurring protein-tyrosine kinase inhibitor. Biochem Biophys Res Commun 165: 241-245, 1989.
14. Palmieri L, Mameli M and Ronca G: Effect of resveratrol and some other natural compounds on tyrosine kinase activity and on cytolysis. Drugs Exp Clin Res 25: 79-85, 1999.

15. Mishra NC, Sharma M and Sharma A: Inhibitory effect of piceatannol, a protein tyrosine kinase inhibitor, on asexual maturation of Plasmodium falciparum. Indian J Exp Biol 37: 418-420, 1999.

16. Su L and David M: Distinct mechanisms of STAT phosphorylation via the interferon-alpha/beta receptor. Selective inhibition of STAT3 and STAT5 by piceatannol. J Biol Chem 275: 12661-12666, 2000

17. Balaian L, Zhong RK and Ball ED: The inhibitory effect of antiCD33 monoclonal antibodies on AML cell growth correlates with Syk and/or ZAP-70 expression. Exp Hematol 31: 363-371, 2003.

18. Chen L, Apgar J, Huynh L, Dicker F, Giago-McGahan T, Rassenti L, Weiss A and Kipps TJ: ZAP-70 directly enhances IgM signaling in chronic lymphocytic leukemia. Blood 105: 2036-2041, 2005.

19. Fontecave M, Lepoivre M, Elleingand E, Gerez C and Guittet O: Resveratrol, a remarkable inhibitor of ribonucleotide reductase. FEBS Lett 421: 277-279, 1998.

20. Elford HL, Freese M, Passamani E and Morris HP: Ribonucleotide reductase and cell proliferation. I. Variations of ribonucleotide reductase activity with tumor growth rate in a series of rat hepatomas. J Biol Chem 245: 5228-5233, 1970.

21. Heinemann V, Xu YZ, Chubb S, Sen A, Hertel LW, Grindey GB and Plunkett W: Inhibition of ribonucleotide reduction in CCRF- CEM cells by 2',2'-difluorodeoxycytidine. Mol Pharmacol 38: 567-572, 1990.

22. Gandhi V and Plunkett W: Cellular and clinical pharmacology of fludarabine. Clin Pharmacokinet 41: 93-103, 2002.

23. Fritzer-Szekeres M, Salamon A, Grusch M, Horvath Z, Hochtl T, Steinbrugger R, Jager W, Krupitza G, Elford HL and Szekeres T: Trimidox, an inhibitor of ribonucleotide reductase, synergistically enhances the inhibition of colony formation by Ara-C in HL-60 human promyelocytic leukemia cells. Biochem Pharmacol 64: 481-485, 2002.

24. Garrett C and Santi DV: A rapid and sensitive high pressure liquid chromatography assay for deoxyribonucleoside triphosphates in cell extracts. Anal Biochem 99: 268-273, 1979.

25. Chou TC and Talalay P: Quantitative analysis of dose-effect relationships: the combined effects of multiple drugs or enzyme inhibitors. Adv Enzyme Regul 22: 27-55, 1984.

26. Murias M, Handler N, Erker T, Pleban K, Ecker G, Saiko P, Szekeres $\mathrm{T}$ and Jager W: Resveratrol analogues as selective cyclooxygenase-2 inhibitors: synthesis and structure-activity relationship. Bioorg Med Chem 12: 5571-5578, 2004.

27. Wung BS, Hsu MC, Wu CC and Hsieh CW: Piceatannol upregulates endothelial heme oxygenase-1 expression via novel protein kinase $\mathrm{C}$ and tyrosine kinase pathways. Pharmacol Res 53: 113-122, 2006.

28. Islam S, Hassan F, Mu MM, Ito H, Koide N, Mori I, Yoshida T and Yokochi T: Piceatannol prevents lipopolysaccharide (LPS)-induced nitric oxide (NO) production and nuclear factor (NF)-kappaB activation by inhibiting IkappaB kinase (IKK). Microbiol Immunol 48: 729-736, 2004.

29. Ashikawa K, Majumdar S, Banerjee S, Bharti AC, Shishodia S and Aggarwal BB: Piceatannol inhibits TNF-induced NF-kappaB activation and NF-kappaB-mediated gene expression through suppression of IkappaBalpha kinase and p65 phosphorylation. J Immunol 169: 6490-6497, 2002.

30. Nakamura N and Wada Y: Properties of DNA fragmentation activity generated by ATP depletion. Cell Death Differ 7: 477-484, 2000.

31. Ferrigni NR, McLaughlin JL, Powell RG and Smith CR Jr: Use of potato disc and brine shrimp bioassays to detect activity and isolate piceatannol as the antileukemic principle from the seeds of Euphorbia lagascae. J Nat Prod 47: 347-352, 1984.

32. Nuckel H, Rebmann V, Durig J, Duhrsen U and Grosse-Wilde H: HLA-G expression is associated with an unfavorable outcome and immunodeficiency in chronic lymphocytic leukemia. Blood 105: 1694-1698, 2005.

33. Hamblin TJ: Predicting Progression - ZAP-70 in CLL. N Engl J Med 351: 856-857, 2004. 